\title{
GAMBARAN TINGKAT PENGETAHUAN DAN PRAKTIK MENSTRUAL HYGIENE SISWI SDN 4 PACARKEMBANG SURABAYA
}

\author{
THE DESCRIPTION OF THE KNOWLEDGE AND PRACTICE LEVEL \\ OF MENSTRUAL HYGIENE ON FEMALE STUDENT AT SDN 4 \\ PACARKEMBANG SURABAYA
}

\author{
Teresina Ika Pertiwi ${ }^{1)}$, Hario Megatsari ${ }^{2)}$ \\ ${ }^{1}$ Departemen Promosi Kesehatan dan Ilmu Perilaku \\ ${ }^{2}$ Perhimpunan Sarjana dan Profesional Kesehatan Masyarakat Indonesia \\ Fakultas Kesehatan Masyarakat Universitas Airlangga, Surabaya \\ Email: teresina.ika.pertiwi-2015@fkm.unair.ac.id
}

\begin{abstract}
Adolescence is an important period to develop the first decade of life. At this age, adolescent girl begin to get their first menstrual period (menarche). After getting menstruation, adolescent girls need to know how to maintain their reproductive health. One effort that can be done to take care of the reproductive health is adopt the behavior of menstrual hygiene. This study aims to determine the level of knowledge of elementary school girls about reproductive health and menstrual hygiene behavior in the period of menarche. The population of this study was all students grades 5 and 6 at SDN 4 Pacarkembang Surabaya and already experienced menarche. This study has 30 samples and the method of data collection conducted by survey method using a questionnaire with closed questions. The variables are categorized into three categories: good knowledge level if the score range between 76-100\%, the level of knowledge sufficient if the range between 56-75\%, and the level of knowledge is deficient when the score $<56 \%$. The action variable using the same category with the level of knowledge. The average age of menarche here is 11-12 years old. All of respondents had got information of health reproduction and menstruation. Most respondents had heard that information from their mother. But majority of respondents have "less" knowledge (53.33\%) of health reproduction and sufficient behaviour of menstrual hygiene $(60.0 \%)$.
\end{abstract}

Keyword: health reproduction, menstrual hygiene, adolencence, menarche

\begin{abstract}
Abstrak: Masa remaja menjadi waktu yang sangat penting untuk membangun perkembangan mereka dalam dekade pertama kehidupan. Pada usia ini, remaja putri mulai mendapatkan menstruasi pertamanya (menarche). Setelah mendapatkan haid, remaja putri perlu mengetahui cara menjaga kesehatan reproduksinya. Salah satu upaya yang dapat dilakukan untuk menjaga kesehatan reproduksi adalah dengan menerapkan praktik menstrual hygiene. Penelitian ini bertujuan untuk mengetahui tingkat pengetahuan remaja putri sekolah dasar mengenai kesehatan reproduksi dan praktik menstrual hygiene pada periode menarche. Populasi penelitian adalah seluruh siswi kelas 5 dan 6 yang sudah melalui masa menarche di SDN 4 Pacarkembang Surabaya. Jumlah sampel yang digunakan adalah sejumlah 30 sampel. Penelitian ini merupakan penelitian deskriptif kuantitatif dan menggunakan total populasi sebagai responden. Cara pengumpulan data dilakukan dengan metode survei menggunakan instrumen kuesioner dengan pertanyaan tertutup. Variabel dikategorikan menjadi tiga kategori yaitu tingkat pengetahuan baik apabila skor 76-100\%, tingkat pengetahuan cukup apabila skor 56-75\%, dan tingkat pengetahuan kurang apabila skor $<56 \%$. Variabel tindakan menggunakan kategori serupa dengan tingkat pengetahuan. Hasil rata-rata usia menarche responden adalah usia 11 sampai dengan 12 tahun. Hampir seluruh responden sudah mendapatkan informasi terkait menstrual hygiene sebelum responden mengalami menarche dari orang tua perempuan responden. Namun sebagian
\end{abstract}


besar responden memiliki tingkat pengetahuan yang kurang (53.33\%) dan perilaku menstrual hygiene responden sudah cukup baik (60.0\%).

Keyword: kesehatan reproduksi, menstrual hygiene, remaja, menarche

\section{PENDAHULUAN}

Remaja dapat diartikan sebagai suatu tahapan seseorang yang berada diantara fase anak dan dewasa yang ditandai dengan perubahan fisik, perilaku, kognitif, biologis, dan emosi (Efendi dan Makhfudli, 2009). Rentang usia yang digunakan untuk mengklasifikasikan usia remaja dikategorikan menjadi beberapa tahapan dan didefinisikan dengan berbagai cara. Pengklasifikasian umur digunakan untuk membedakan antar remaja menurut perkembangan fisik yang mereka alami. Terjadi jurang perbedaan manifestasi yang sangat besar antara awal dan akhir rentang usia remaja. Untuk mengatasi perbedaan yang terlalu besar tersebut, UNICEF (2011) membagi usia remaja menjadi dua bagian yaitu usia 1014 tahun sebagai remaja awal dan usia 15-19 years sebagai usia remaja akhir. Sawyer, et.al (2012) mengambil tiga kategori usia untuk anak muda yaitu usia 10-14 tahun sebagai kategori remaja awal (early adolescence), 15-19 tahun sebagai remaja akhir (late adolescence), dan usia 20-24 tahun sebagai dewasa muda (young adulthood) sehingga menurut pandangan ini usia remaja juga memiliki dua kategori rentang usia. Definisi yang dibuat oleh Departemen Kesehatan Indonesia membatasi usia yang termasuk kelompok remaja yaitu meliputi penduduk berusia 10-19 tahun dan belum kawin (Badan Pusat Statistik, 2008). Berdasarkan batasan tersebut Kementerian Kesehatan juga membagi rentang tersebut menjadi 3 kategori usia remaja yaitu masa remaja awal dengan rentang usia 10-13 tahun, remaja pertengahan yaitu usia 14-16 tahun, dan remaja akhir yaitu usia 17-19 tahun (Kemenkes RI, 2011).

Masa remaja merupakan usia yang menjadi masa yang baik (menjadi suatu bentuk kesempatan) bagi anak-anak dan menjadi waktu yang sangat penting untuk membangun perkembangan mereka dalam dekade pertama kehidupan, membantu mereka dalam menavigasi atau mencari jalan bagi risiko dan kerentanan, serta mengatur untuk memenuhi potensi mereka (UNICEF, 2011). Berbagai perubahan biologis juga terjadi selama masa remaja pada laki-laki dan perempuan. Anak gadis remaja mengalami salah satu peristiwa penting yaitu haid (menstruasi) (Wijaya, Suryatin, dan Salirawati, 2008). Pada usia ini, remaja putri mulai mendapatkan menstruasi pertamanya atau disebut juga dengan menarche. Menars atau menarche adalah perdarahan pertama dari uterus yang terjadi pada seorang wanita (Prawirohardjo, 2010). Menarche merupakan suatu puncak dari serangkaian perubahan seorang gadis yang sedang menginjak dewasa. Serangkaian interaksi antara beberapa kelenjar di dalam tubuh menjadi penyebab timbulnya serangkaian perubahan (Wijaya, Suryatin, dan Salirawati, 2008). Menurut Prawirohardjo, (2010), rentang usia antara 11 - 13 tahun merupakan usia rata-rata remaja perempuan mengalami masa menarche.

Setelah mendapatkan haid, remaja putri perlu mengetahui cara menjaga kesehatan reproduksinya. Salah satu upaya yang dapat dilakukan untuk menjaga kesehatan reproduksi adalah dengan menerapkan praktik menstrual hygiene. Menstrual hygiene diartikan oleh Clement (2012), sebagai bentuk perhatian atau perawatan simpatik, emosional, dan perhatian pada kebersihan yang diberikan selama periode menstruasi. Perilaku yang termasuk dalam perilaku menstrual hygiene yaitu perawatan area genital, pembalut (sanitary napkin), personal hygiene, diet, dan olah raga (Clement, 2012). Perilaku ini sangat penting untuk mencegah infeksi sistem reproduksi, gangguan lokal seperti rasa gatal dan bau yang tidak sedap pada area genital.

United Nations (2014), mengadopsi hasil dari International Conference on Population and Development (ICPD) Kairo, 5-13 September 1994 untuk 
mendefinisikan kesehatan reproduksi yaitu suatu kelengkapan fisik, mental, dan kesejahteraan sosial, dan tidak hanya mengenai ketiadaan penyakit dan kelemahan, tetapi mengenai segala hal yang berkaitan sengan sistem reproduksi termasuk fungsi dan prosesnya. Berdasarkan hasil penelitian sebelumnya yang melibatkan anak usia menarche (siswa sekolah dasar kelas IV, V, dan VI) menunjukkan hasil bahwa sebagian besar yaitu $89,1 \%$ dari seluruh responden cenderung memiliki pengetahuan yang kurang mengenai kesehatan reproduksi terutama mengenai menstruasi (Afriliana, dkk, 2014). Berdasarkan hasil penelitian tersebut dapat diketahui bahwa masih rendahnya pengetahuan remaja mengenai kesehatan reproduksi padahal kesehatan reproduksi merupakan bagian penting dari siklus reproduksi yang dialami oleh wanita. Hasil penelitian tersebut juga membawa pemahaman mengenai kesehatan reproduksi perlu diperkuat sejak awal siklus reproduksi yaitu pada masa pubertas. Survei Kesehatan Reproduksi Remaja Indonesia (SKRRI) yang dilaksanakan tahun 2007 menyebutkan bahwa pertumbuhan payudara dan menstruasi merupakan pengetahuan mengenai perubahan fisik dari seorang anak perempuan yang umum diketahui oleh sebagian besar remaja perempuan yaitu sebesar $56 \%$ remaja menjawab terjadinya pertumbuhan payudara dan $76 \%$ remaja menjawab menstruasi merupakan ciri utama seorang perempuan mengalami pubertas.

Anak usia sekolah perlu diberi pengetahuan mengenai fungsi alat reproduksi, perubahan yang terjadi pada masa ini, kebersihan diri ketika mendapatkan menstruasi, pengetahuan tentang proses kehamilan, dan masalah reproduksi remaja (Noorkasiani, Heryati, dan Ismail, 2009). Pemberian pengetahuan mengenai kesehatan reproduksi diperlukan karena fase perubahan organ dan fungsi reproduksi mulai terjadi pada usia remaja yang juga masuk ke dalam usia sekolah. Selain karena faktor usia, faktor reaksi pada remaja terhadap datangnya haid pertama atau menarche juga dapat menjadi alasan pentingnya pemberian pengetahuan mengenai kesehatan reproduksi pada anak usia sekolah. Mansur dan Budiarti (2014), membagi reaksi remaja terhadap datangnya menstuasi pertama menjadi dua macam, yaitu reaksi positif dan reaksi negatif. Seorang individu disebut menunjukkan reaksi positif jika individu tersebut mampu menghargai, memahami dan menerima menstruasi pertama sebagai suatu tanda kedewasaan yang dimiliki seorang wanita. Adanya kemampuan untuk melihat gambaran diri mengenai kelebihan dan kekurangan diri sendiri yang membuat mereka mampu untuk dapat melakukan evaluasi terhadap diri sendiri menjadi suatu tanda bahwa individu tersebut memiliki konsep diri (self concept) yang positif.

Konsep diri yang dapat menunjukkan bahwa individu tersebut memberikan reaksi positif terhadap datangnya menstruasi pertama. Sementara individu disebut menunjukkan reaksi negatif mengenai datangnya menstruasi pertama adalah ketika dirinya memandang munculnya menstruasi pertama dengan kurang baik. Individu memandang keluhan fisiologis mengenai menstruasi menjadi sesuatu yang kurang baik dan kondisi psikologis yang tidak stabil juga menjadi penunjuk bahwa individu tersebut memberikan reaksi negatif terhadap fenomena menarche yang dialami dirinya. Oleh karena itu, pemberian pengetahuan terkait kesehatan reproduksi pada anak usia sekolah sekolah perlu diberikan karena periode menstruasi pertama terjadi pada usia ini dan sebagai bentuk persiapan terhadap reaksi terhadap menarche yang akan timbul.

Pemaparan berkenaan dengan usia menarche dapat diartikan bahwa rentang usia sekolah dasar merupakan usia saat remaja putri mulai mendapat haid pertamanya. Periode ini juga merupakan pengalaman pertama remaja putri beradaptasi dengan perubahan pada dirinya berupa praktik menstrual hygiene yang seharusnya dilakukan untuk menjaga kesehatan reproduksi. Berdasarkan pemaparan tersebut maka penelitian ini bertujuan untuk mengetahui dan mengidentifikasi gambaran tingkat pengetahuan kesehatan reproduksi serta 
praktik menstrual hygiene pada siswa sekolah dasar.

\section{METODE}

Penelitian ini menggunakan metode penelitian kuantitatif deskriptif dengan rancangan penelitian yang menggunakan pendekatan cross sectional yaitu pengukuran variabel pengetahuan dan sikap pada penelitian ini dilakukan pada satu saat tertentu. Cross sectional dilakukan untuk mempelajari hubungan antara variabel bebas dengan variabel terikat yang dilakukan satu kali dan dalam waktu yang bersamaan (Nova Oktavia, 2015).

Penelitian dilakukan di SDN 4 Pacarkembang Surabaya pada tanggal 06 Maret 2017. Populasi penelitian ini menggunakan kriteria inklusi yang sudah ditentukan sebelumnya yaitu seluruh siswi kelas 5 dan 6 yang sudah melalui masa menarche. Sampel penelitian menggunakan keseluruhan jumlah populasi atau menggunakan total population sejumlah 30 responden.

Cara pengumpulan data dilakukan dengan metode survei menggunakan instrumen kuesioner dengan pertanyaan tertutup. Konten kuesioner berisi pertanyaan untuk mengukur tingkat pengetahuan dan praktik/tindakan responden.

Sebelum proses analisa data dilakukan, data yang didapatkan dikategorikan terlebih dahulu. Data mengenai variabel pengetahuan diolah dengan cara memasukkan data tersebut dalam tabel distribusi frekuensi sesuai dengan variabelnya. Variabel juga dikategorikan menjadi tiga kategori misalnya tingkat pengetahuan, yaitu tingkat pengetahuan baik apabila skor 76$100 \%$, tingkat pengetahuan cukup apabila skor $56-75 \%$, dan tingkat pengetahuan kurang apabila skor $<56 \%$ (Nursalam, 2008).

\section{HASIL DAN PEMBAHASAN}

\section{Karakteristik Responden}

Hasil penelitian mendapatkan karakteristik responden berdasarkan usia responden, usia menarche, cara mendapatkan informasi mengenai kesehatan reproduksi, dan pihak pemberi informasi kesehatan reproduksi.

Tabel 1. Karakteristik Responden Berdasarkan Usia Responden dan Usia Menarcha

\begin{tabular}{ccc}
\hline Karakteristik & Frekuensi & Persentase \\
\hline $\begin{array}{c}\text { Usia } \\
\text { Responden }\end{array}$ & & \\
\hline 11 th & 5 & 16.67 \\
\hline 12 th & 18 & 60.00 \\
\hline 13 th & 7 & 23.33 \\
\hline Total & 30 & 100 \\
\hline $\begin{array}{c}\text { Usia } \\
\text { Menarche }\end{array}$ & & \\
\hline 10 th & 4 & 13.33 \\
\hline 11 th & 13 & 43.33 \\
\hline 12 th & 13 & 43.33 \\
\hline Total & 30 & 100 \\
\hline
\end{tabular}

Berdasarkan tabel 1 dapat diketahui bahwa lebih dari separuh dari total responden memiliki karakteristik usia 12 tahun. Sebagian besar usia menarche yang dialami responden adalah ketika responden berusia 11 dan 12 tahun dengan persentase antara usia 11 tahun sama besar dengan usia 12 tahun. Selain data karakteristik usia, cara mendapatkan informasi dan sumber informasi mengenai kesehatan resproduksi yang dimiliki responden menunjukkan $100 \%$ responden sudah pernah mendapatkan informasi mengenai kesehatan reproduksi tepatnya informasi seputar menstruasi. Informasi mengenai kesehatan reproduksi dan mengenai kesehatan reproduksi wanita lainnya belum pernah didapatkan oleh responden. Dari keseluruhan responden tersebut, hampir seluruh responden mendapatkan informasi mengenai kesehatan reproduksi seputar menstruasi dari pihak orang tua tepatnya ibu dan hanya sebagian kecil yaitu $3.33 \%$ responden mendapatkan informasi mengenai kesehatan reproduksi dari pihak guru sekolah.

\section{Pengetahuan Responden Mengenai Kesehatan Reproduksi}


Penilaian pengetahuan mengenai kesehatan reproduksi dilakukan dengan menggunakan batasan indikator "tahu" dan "memahami". Batasan mengenai pengetahuan tersebut disesuaikan dengan materi kesehatan reproduksi yang ada dalam kurikulum atau mata pelajaran siswa sekolah dasar sehingga indikator pengetahuan tidak jauh dari kemampuan responden. Indikator materi yang digunakan dalam pengukuran kuisionair pun diadaptasi dari berbagai sumber dan disesuaikan dengan buku mata pelajaran biologi untuk sekolah dasar dengan materi kesehatan reproduksi. Berikut ini indikator pengetahuan yang dirangkum dalam 8 poin penilaian:

1. Pengertian menstruasi (Wateraid, 2013)

2. Sebutan lain dari menstruasi (Sulistyowati dan Sukarno, 2006)

3. Fisiologis menstruasi (Sulistyanto, Heri dan Edy W, 2008)

4. Alat reproduksi internal perempuan (Pitoyo, Ari dan Sri P, 2010)

5. Sebab keluarnya darah saat menstruasi (Pitoyo, Ari dan Sri P, 2010)

6. Periode menstruasi normal Sulistyanto, Heri dan Edy W, 2008)

7. Frekuensi penggantian pembalut yang ideal (Mianoki, Andika, dkk, 2014)

8. Cara yang benar untuk membersihkan organ genitalia saat menstruasi (House S, T. Mahon, S Cavill, 2012)

$\begin{array}{clr}\text { Poin } & \text { pertama } & \text { pengetahuan } \\ \text { responden } & \text { mengenai } & \text { pengertian }\end{array}$ menstruasi mendapatkan hasil yaitu sebagian besar responden menjawab dengan benar. Sebesar $53.33 \%$ responden menjawab menstruasi adalah keluarya sel telur dari indung telur yang tidak dibuahi bersama lapisan dinding rahim yang banyak mengandung pembuluh darah. pada poin pertama ini merupakan jawaban yang benar. Sementara pada poin kedua sebesar $33.33 \%$ responden menjawab menstruasi adalah keluarnya darah dari organ genitalia karena penyakit sementara sisanya menjawab menstruasi adalah keadaan sakit perut selama satu minggu.

Poin ke dua pengetahuan responden mengenai sebutan lain dari menstruasi mendapatkan hasil bahwa hampir seluruh responden menjawab pertanyaan dengan benar. Sebesar $96.67 \%$ responden menjawab nama lain dari menstruasi adalah "haid". Hasil penelitian pada poin ke tiga pengetahuan responden mengenai fisiologi menstruasi menunjukkan lebih dari separuh responden sudah mengetahui bahwa menstruasi merupakan proses biologis yang normal. Sebesar $60.00 \%$ responden menjawab pertanyaan dengan benar. $23.3 \%$ responden menjawab menstruasi adalah suatu penyakit dan $16.67 \%$ responden menjawab menstruasi merupakan pertanda adanya kelainan pada organ reproduksi.

Hasil penelitian pada poin ke empat pengetahuan responden mengenai nama alat reproduksi internal yang dimiliki perempuan mendapatkan hasil sebagian besar responden belum mengetahui nama alat reproduksi internal wanita sehingga hanya sepertiga responden yang menjawab pertanyaan dengan benar. Persentase jawaban yang didapatkan adalah $10.00 \%$ responden menjawab payudara, $36.67 \%$ responden menjawab Rahim (uterus), dan $53.33 \%$ responden menjawab saluran kencing sebagai nama alat reproduksi internal perempuan.

Hasil penelitian pada poin ke lima pengetahuan responden mengenai sebab keluarnya darah menstruasi menunjukkan bahwa distribusi jawaban responden tidak merata karena sebagian besar responden menjawab pada opsi jawaban yang sama dan terdapat opsi jawaban yang tidak di pilih. Namun, sebagian besar opsi yang di pilih merupakan opsi jawaban benar. Sebesar $76.67 \%$ responden menjawab keluarnya darah menstruasi disebabkan karena terjadi pelepasan sel telur yang diikuti dengan pelepasan lapisan dinding Rahim dan sisanya menjawab keluarnya darah menstruasi disebabkan karena rahim telah terisi darah.

Poin ke enam pengetahuan responden mengenai periode menstruasi normal mendapatkan hasil sebagian besar responden belum mengetahui periode menstruasi yang normal. Hal ini dibuktikan dengan data proporsi jawaban responden yang salah lebih tinggi daripada jawaban benar. Persentase jawaban responden yaitu sebesar $63.33 \%$ responden menjawab menstruasi terjadi satu minggu sekali, 33,3\% responden 
menjawab menstruasi terjadi setiap 28 hari sekali (periode 28 hari), dan responden yang lain menjawab menstruasi terjadi setiap dua belas hari sekali (periode 12 hari).

Hasil penelitian pada poin ke tujuh pengetahuan responden mengenai frekuensi penggantian pembalut yang ideal mendapatkan hasil sebagian besar responden belum mengetahui frekuensi penggantian pembalut yang ideal. Hal ini dibuktikan dengan data proporsi jawaban responden yang salah lebih tinggi daripada jawaban benar. Persentase pilihan jawaban responden yaitu $46.67 \%$ responden menjawab pembalut perlu diganti empat sampai lima kali sehari, $36.67 \%$ responden menjawab pembalut perlu diganti saat pembalut sudah penuh saja, dan $16.67 \%$ responden menjawab pembalut perlu di ganti dua kali sehari saat mandi saja.

Hasil penelitian pada poin ke delapan pengetahuan responden mengenai cara yang benar untuk membersihkan organ genitalia saat sedang menstruasi mendapatkan hasil sebagian besar responden belum mengetahui cara yang benar untuk membersihkan organ genitalia. Hal ini dibuktikan dengan data proporsi jawaban responden yang salah lebih tinggi daripada jawaban benar. Sebesar $73.33 \%$ responden memilih jawaban membersihkan organ genitalia dengan air dan sabun khusus pembersih organ genitalia untuk menjawab pertanyaan poin delapan, $16.67 \%$ responden memilih opsi jawaban membersihkan organ genitalia dibersihkan dengan air saja atau dengan sabun yang tidak merubah keseimbangan $\mathrm{PH}$ organ genitalia, dan responden lainnya memilih opsi jawaban membersihkan organ genitalia dengan air dan sabun mandi sebagai jawaban dari pertanyaan poin delapan.

Hasil pada tabel 2 dapat diketahui mengenai poin penilaian yang paling banyak mendapatkan jawaban benar maupun jawaban salah. Hampir seluruh responden mampu menjawab poin 2 dengan benar yaitu "haid" merupakan sebutan lain dari menstruasi. Sementara untuk poin yang paling banyak mendapat opsi jawaban salah adalah poin nomor 8 mengenai cara yang benar untuk membersihkan organ genitalia.

Tabel 2. Hasil Tabulasi Poin Penilaian Pengetahuan Responden

\begin{tabular}{ccccr}
\hline $\begin{array}{c}\text { Poi } \\
\text { n }\end{array}$ & $\begin{array}{c}\text { Jawaban } \\
\text { Benar }\end{array}$ & $\%$ & $\begin{array}{c}\text { Jawaba } \\
\text { n Salah }\end{array}$ & $\%$ \\
\hline 1 & 16 & 53.33 & 14 & 46.67 \\
\hline 2 & 29 & 96.67 & 1 & 3.33 \\
\hline 3 & 18 & 60.00 & 12 & 40.00 \\
\hline 4 & 11 & 36.67 & 19 & 63.33 \\
\hline 5 & 23 & 76.67 & 7 & 23.33 \\
\hline 6 & 10 & 33.33 & 20 & 66.67 \\
\hline 7 & 14 & 46.67 & 16 & 53.33 \\
\hline 8 & 5 & 16.67 & 25 & 83.33 \\
\hline
\end{tabular}

Tabel 3 menunjukkan hasil dari poin penilaian pengetahuan yang sudah di kategorisasi menjadi tiga tingkatan.

Tabel 3. Tingkat Pengetahuan Siswa SDN 4 Pacarkembang Surabaya Mengenai Reproduksi

\begin{tabular}{ccc}
\hline $\begin{array}{c}\text { Tingkat } \\
\text { Pengetahuan }\end{array}$ & Frekuensi & \% \\
\hline Baik & 3 & 10.00 \\
\hline Cukup & 11 & 36.66 \\
\hline Kurang & 16 & 53.33 \\
\hline Total & 30 & 100 \\
\hline
\end{tabular}

Berdasarkan hasil pengkategorian sebagian besar responden memiliki tingkat pengetahuan mengenai kesehatan reproduksi yang kurang dan sebagian kecil saja memiliki tingkat pengetahuan yang baik mengenai kesehatan reproduksi.

Jean Piaget dengan teorinya menjelaskan bahwa anak akan mengalami proses perkembangan kognitif secara periodik. Perkembangan tersebut terbagi menjadi menjadi empat tahap yaitu tahap sensorimotor yang terjadi pada usia 0 - 2 tahun, tahap pra operasi yang terjadi pada anak usia $2-7$ tahun, tahap operasi konkret pada usia 8 - 11 tahun, dan operasi formal yang terjadi pada anak usia 11 tahun ke atas. Setiap anak akan mengalami tahap ini walaupun dengan usia yang berbeda-beda (dalam rentang 
usia yang tidak berbeda jauh). Seorang anak dapat memulai tahap formalnya pada usia 11 tahun sedangkan anak yang lainnya dapat memulai tahap formalnya pada usia 15 tahun (Suparno, 2001). Usia pada tahap operasi formal ini juga dapat dikategorikan menjadi usia remaja bila dikaitkan dengan rentang usia oleh UNICEF maupun Badan Pusat Statistik Indonesia.

Karakteristik usia responden dalam penelitian ini ada pada rentang usia 11 13 tahun. Usia ini dapat masuk dalam tahap operasi konkret atau tahap operasi formal. Dalam tahap ini salah satu ciri perkembangan kognitifnya yaitu berupa hipotesis atau asumsi, abstrak, bersifat secara deduksi dan induksi, serta dapat berfikir secara logis dan maupun berdasarkan aspek probabilitas atau kemungkinan (Suparno, 2001). Kemampuan membandingkan dan membuat pemikiran secara abstrak serta mampu menarik kesimpulan dari informasi yang didapatkan juga terjadi pada tahap operasi formal. Selain itu tahap ini terjadi perkembangan kemampuan untuk mempertimbangkan konsep bersifat hipotetik dan mereka dapat menggunakan penalaran untuk memecahkan masalah dan mempertimbangkan penyelesaian alternatif (Allen, 2016).

Pemberian pengetahuan terarah perlu dilakukan agar penarikan kesimpulan sebagai bentuk pemahaman pada tahap ini dapat terjadi dengan aman dan benar. Pemberian pengetahuan yang cukup dan sesuai dengan proporsi juga dapat membantu dalam proses penalaran di tahap operasi formal. Notoatmodjo, 2012, didalam bukunya berpendapat mengenai pengetahuan atau ranah kognitif bahwa pengetahuan merupakan suatu domain yang sangat penting dalam membentuk tindakan seseorang. Bila mengacu pada pendapat Notoatmodjo, maka terdapat pengaruh antara pengetahuan dan tindakan seseorang walaupun arah tindakan menjadi positif maupun negatif masih perlu dilakukan penelitian terlebih dahulu.

Pada penelitian ini didapatkan gambaran hasil bahwa separuh dari total responden memiliki tingkat pengetahuan mengenai kesehatan reproduksi yang kurang dan sebagian kecil saja memiliki tingkat pengetahuan yang baik. Poin 8 mengenai cara yang benar untuk membersihkan organ genitalia saat sedang menstruasi menjadi poin dengan perolehan persentase kesalahan terbesar yaitu $83.33 \%$ dari total responden. Berdasarkan hasil tersebut bisa diketahui bahwa sebagian besar responden belum melakukan tindakan membersihkan organ genetalia dengan benar. Secara fisiologis, pembersihan tersebut tidak bisa dilakukan dengan cara yang asal. Menurut Azzam, 2012, membersihkan organ genetalia yang benar adalah dengan membasuhnya menggunakan air bersih mengalir dan dibarengi oleh mengusap organ dari arah depan ke belakang. Pengetahuan pada poin 8 merupakan ruang lingkup dari kesehatan reproduksi dan masuk dalam pengetahuan mengenai menstrual hygiene maupun personal hygiene yang benar. Pengenalan terhadap organ reproduksi perempuan serta siklus menstruasi normal juga menjadi salah satu poin pengetahuan yang masih belum diketahui oleh sebagian besar responden. Kurangnya pengetahuan tentang personal hygiene saat menstruasi atau bisa disebut juga sebagai menstrual hygiene pada sebagian remaja putri mengindikasikan bahwa selayaknya para remaja putri memperoleh informasi tentang menstruasi. Pendekatan yang bisa dilakukan diantaranya melalui keluarga, kelompok sebaya, institusi sekolah, serta kelompok kegiatan remaja yang peduli terhadap masa puber (Novianti, Yasnani, dan Erawan, 2016).

Psikologis remaja harus dipersiapkan untuk menghadapi menarche sehingga remaja dapat menghadapi proses menarche dengan sehat. Pemberian informasi mengenai sedini mungkin merupakan salah satu bentuk persiapan untuk remaja. Tujuan pemberian informasi ini adalah agar remaja tahu bahwa menarche adalah tanda seorang anak perempuan beralih menjadi dewasa. Membantu remaja mempersiapkan diri dalam menghadapi menarche juga menjadi salah satu tujuan pemberian informasi (Nurmawati dan Erawantini, 2016). Pengetahuan didapatkan dari pendidikan atau edukasi. Mantra, tokoh utama dalam penyuluhan kesehatan 
Indonesia, menerapkan strategi dengan pendekatan edukatif untuk membentuk kebiasaan hidup sehat di masyarakat. Edukasi dan pengetahuan akan merangsang potensi individu dalam menentukan pilihan untuk tindakan yang berkaitan dengan kesehatan serna mendorong individu tersebut untuk mengatasi permasalahan kesehatan mereka (Alhamda, 2015). Jika dikaitkan antara pendapat Mantra dan penelitian ini, maka diperlukan pengetahuan yang memadai agar remaja dapat membiasakan hidup sehat dengan melakukan praktik menstrual hygiene.

\section{Praktik Menstrual Hygiene}

Penilaian praktik menstrual hygiene menggunakan delapan batasan konsep. Poin penilaian ini sebagian besar diadaptasi dari House S, T. Mahon, S Cavill, 2012, dan disesuaikan dengan batasan pada kurikulum mata pelajaran biologi untuk sekolah dasar mengenai pubertas. Berikut poin yang digunakan:

1. Jenis pembalut yang digunakan

2. Frekuensi penggantian pembalut dalam waktu satu hari pada saat menstruasi

3. Prosedur yang dilakukan sebelum membersihkan organ genitalia

4. Cara membersihkan organ genitalia

5. Bahan pembersih yang digunakan untuk membersihkan organ genitalia

6. Perlakuan terhadap pembalut yang telah digunakan

7. Perilaku pembuangan pembalut yang telah digunakan

8. Perlakuan terhadap pakaian dalam yang terkena darah menstruasi (Clement, I, 2012)

Hasil penelitian pada poin pertama perilaku responden mengenai jenis pembalut yang digunakan responden mendapatkan hasil hampir seluruh responden memilih opsi yang diharapkan sebagai perilaku pada saat menghadapi periode menstruasi. Persentase jawaban untuk poin pertama ini yaitu $96.7 \%$ responden menggunakan pembalut sekali pakai (disposable) dan 3.33\% responden menggunakan pembalut cuci pakai.

Frekuensi penggantian pembalut dalam waktu satu hari saat menstruasi sebagai poin ke dua perilaku responden menunjukkan hasil sebesar $46.7 \%$ responden mengganti pembalut sejumlah dua kali sehari, $33.3 \%$ responden mengganti pembalut lebih dari tiga kali sehari, dan 20\% responden mengganti pembalut sejumlah tiga kali sehari. Hasil ini menunjukkan kurang dari separuh responden memilih opsi yang benar yaitu mengganti pembalut lebih dari tiga kali sehari sebagai opsi yang benar. Berdasarkan jawaban responden ini menggambarkan bahwa sebagian besar responden belum melakukan penggantian pembalut sesuai dengan keadaan semestinya atau perilaku benar yang disarankan.

Opsi jawaban yang menunjukkan perilaku benar pada poin ke tiga perilaku responden menganai prosedur yang dilakukan responden sebelum membersihkan organ genitalia adalah opsi "mencuci tangan dengan sabun dan air bersih". Persentase pilihan opsi jawaban responden yaitu $83.3 \%$ responden melakukan cuci tangan dengan sabun dan air bersih, $13.3 \%$ responden melakukan cuci tangan dengan air saja, dan sejumlah $3.33 \%$ responden hanya mengelap tangan dengan handuk sebelum membersihkan organ genitalia. Hasil pada poin tiga menunjukkan sebagian besar responden sudah berperilaku dengan benar.

Opsi jawaban yang menunjukkan perilaku benar pada poin ke empat adalah opsi "membersihkan organ genitalia dengan air bersih dari arah depan (organ genitalia) ke belakang (anus)" sebagai cara untuk membersihkan organ genitalia. Persentase pilihan opsi jawaban responden yaitu $76.7 \%$ responden membersihkan organ genitalia dengan air bersih dari arah depan (organ genitalia) ke belakang (anus), 20,0\% responden membersihkan organ genitalia dengan air bersih dari arah belakang (anus) ke depan (organ genitalia), 3.33\% responden hanya membasahi organ genitalia dengan air. Hasil pada poin ini menunjukkan lebih dari setengah total responden sudah berperilaku dengan benar.

Poin ke lima mengenai bahan yang digunakan responden untuk membersihkan organ genitalia mendapatkan hasil $80.0 \%$ responden membersihkan organ genitalia dengan air 
dan sabun khusus pembersih organ genitalia, $13.3 \%$ responden membersihkan organ genitalia dibersihkan dengan air saja atau dengan sabun yang tidak merubah keseimbangan $\mathrm{PH}$ organ genitalia, dan $6.7 \%$ responden membersihkan organ genitalia dengan air dan sabun mandi.

Poin ke enam mengenai perlakuan responden terhadap pembalut yang telah digunakan mendapatkan hasil bahwa kurang lebih separuh dari total responden sudah melakukan perilaku yang benar terhadap pembalut habis pakai. Persentasi pilihan opsi jawaban responden yaitu $53.3 \%$ responden mencuci pembalut terlebih dahulu lalu dibungkus dengan kertas koran atau kertas bekas kemudian di buang di tempat sampah, $23.3 \%$ responden mencuci pembalut terlebih dahulu kemudian di buang, dan $23.3 \%$ responden langsung membuang pembalut yang telah digunakan.

Poin ke tujuh mengenai perilaku responden memilih tempat membuang pembalut yang telah digunakan mendapatkan hasil hampir seluruh responden telah menunjukkan perilaku membuat sampah pembalut habis pakai dengan benar yaitu membuang sampah tersebut di tempat sampah. Persentase pilihan opsi jawaban responden yaitu 93.3\% responden membuang pembalut habis pakai di tempat sampah dan $6.7 \%$ respoonden membuang pembalut habis pakai di saluran pembuangan air.

Poin ke delapan mengenai perlakuan responden terhadap pakaian dalam yang terkena darah menstruasi mendapatkan hasil yaitu hampir seluruh responden telah melakukan perilaku perlakuan terhadap pakaian dalam yang terkena darah menstruasi dengan benar. Persentase pilihan opsi jawaban responden pada poin ini yaitu $90.0 \%$ responden mencuci dengan menggunakan sabun dan air bersih, kemudian di jemur di bawah sinar matahari langsung dan $10.0 \%$ responden mencuci dengan menggunakan air mengalir saja.

Hasil tabulasi poin praktik menstrual hygiene responden pada tabel 4 dapat dilihat bahwa terdapat tiga poin dari penilaian perilaku yang menunjukkan hasil hampir seluruh responden berperila ku sesuai dengan perilaku ideal yaitu pada poin pertama, poin ke tujuh dan poin delapan. Pada poin pertama hampir seluruh responden telah menggunakan pembalut sekali pakai untuk kebutuhan saat menstruasi. Pada poin ke tujuh menunjukkan bahwa hampir seluruh responden telah membuang sampah pembalut bekas menstruasi di tempat sampah. Pada poin delapan juga menunjukkan hampir seluruh responden dapat memperlakukan pakaian dalam yang terkena darah menstruasi dengan benar. Sementara itu responden sebagian besar belum memiliki perilaku yang benar pada pemilihan bahan untuk membersihkan organ genitalia.

Tabel 4. Hasil Tabulasi Poin Praktik Menstrual Hygiene Responden

\begin{tabular}{ccccr}
\hline $\begin{array}{c}\text { Poin } \\
\text { Penilaian }\end{array}$ & Jawaban & Benar & Jawaban & \multicolumn{3}{c}{ Salah } & \multicolumn{1}{c}{} \\
\hline 1 & 29 & 96.67 & 1 & 3.33 \\
\hline 2 & 10 & 33.33 & 20 & 66.67 \\
\hline 3 & 25 & 83.33 & 5 & 16.67 \\
\hline 4 & 23 & 76.67 & 7 & 23.33 \\
\hline 5 & 4 & 13.33 & 26 & 86.67 \\
\hline 6 & 16 & 53.33 & 14 & 46.67 \\
\hline 7 & 28 & 93.33 & 2 & 6.67 \\
\hline 8 & 27 & 90.00 & 3 & 10.00 \\
\hline
\end{tabular}

Tabel 5. Praktik Menstrual Hygiene Siswa SDN 4 Pacarkembang Surabaya

\begin{tabular}{ccc}
\hline $\begin{array}{c}\text { Jawaban } \\
\text { Responden }\end{array}$ & Frekuensi & \% \\
\hline Baik & 5 & 16.67 \\
\hline Cukup & 18 & 60.00 \\
\hline Kurang & 7 & 23.33 \\
\hline Total & 30 & 100 \\
\hline
\end{tabular}

Pada tabel 5 menunjukkan praktik atau tindakan menstrual hygiene secara keseluruhan pada responden. Lebih dari separuh responden memiliki praktik menstrual hygiene yang cukup baik. Sementara responden lainnya memiliki praktik menstrual hygiene yang baik dan kurang dengan proporsi frekuensi maupun 
persentase yang sama. Namun dari tabel 5 perilaku responden terkait praktik tersebut cenderung kurang ke cukup baik.

Tindakan menstrual hygiene secara keseluruhan pada responden didapatkan hasil lebih dari separuh responden memiliki tindakan menstrual hygiene yang cukup baik. Sementara responden lainnya memiliki praktik menstrual hygiene baik dan kurang dengan proporsi frekuensi maupun persentase yang sama. Sebagian besar responden melakukan praktik menstrual hygiene yang salah pada poin ke lima yaitu mengenai bahan yang digunakan responden untuk membersihkan organ genitalia. Sebagian besar responden melakukan upaya membersihkan organ genitalia menggunakan air dan sabun khusus kewanitaan. Bahan yang paling sesuai untuk membersihkan organ genitalia adalah air bersih dan sabun yang tidak mengubah keseimbangan bakteri normal pada organ genitalia. Ketidakseimbangan bakteri organ genitalia dapat memicu terjadinya infeksi (Andriyani, 2014). Jika ingin menggunakan sabun khusus pembersih disarankan untuk menggunakan sabun yang tidak mengacaukan keseimbangan derajat keasaman organ genitalia (Bahari, 2012).

Sebagian besar responden juga melakukan praktik menstrual hygiene yang salah mengenai frekuensi penggantian pembalut dalam waktu satu hari saat menstruasi. Pada poin kedua ini sebagian besar responden memilih perilaku mengganti pembalut saat menstruasi hanya dua kali dalam waktu satu hari. Idealnya, penggantian pembalut dilakukan sejumbah lebih dari 3 kali sehari atau setiap 3-4 jam sekali (House, Mahon, dan Cavil, 2012). Hal ini tentu menunjukkan bahwa perilaku responden untuk poin frekuensi penggantian pembalut masih belum sesuai dengan keadaan ideal dan termasuk dalam perilaku tidak sehat karena hal ini bila dilakukan dalam jangka waktu panjang dapat menjadi pencetus masalah kesehatan. Heryana (2016), dalam jurnalnya menjelaskan bahwa perilaku sehat adalah perilaku yang dilakukan individu untuk menambah, mengelola dan memelihara kesehatannya.

Sementara kebiasaan sehat adalah perilaku sehat yang sudah terpatri serta secara naluriah atau otomatis diterapkan tanpa sadar. Dari penjelasan ini dapat ditarik pemahaman bahwa ranah perilaku merupakan kombinasi dari kognitif, afektif dan konatif sehingga dalam pelaksanaan tindakan dilakukan secara sadar dan individu tahu serta memutuskan untuk melakukan suatu hal tertentu berbeda dengan kebiasaan. Selanjutnya dalam penjelasan Heryana (2016), disebutkan bahwa kebiasaan sehat lazimnya terbentuk pada usia anak-anak dan pada usia 11-12 tahun kebiasaan tersebut menjadi stabil. Kebiasaan sehat memiliki sifat tidak stabil dan orang lain dapat mempengaruhi kebiasaan tersebut. Penjelasan ini dapat mendukung penelitian yaitu praktik menstrual hygiene perlu diketahui pada usia remaja awal (sesuai dengan usia responden) sehingga dapat mengarahkan individu untuk berperilaku sehat dan memiliki kebiasaan sehat pula sebelum kebiasaan menjadi stabil dan sulit untuk diubah bila kebiasaan tersebut bukan merupakan kebiasaan sehat.

\section{Tabulasi Silang Tingkat Pengetahuan Mengenai Kesehatan Reproduksi dengan Praktik Menstrual Hygiene}

Berdasarkan hasil dari tabulasi silang dapat diketahui bahwa sebagian besar responden memiliki tingkat pengetahuan yang kurang mengenai kesehatan reproduksi. Dari responden yang memiliki pengetahuan kurang, sebagian besar memiliki praktik yang cukup baik. Sementara pada tingkat perilaku menstrual hygiene, sebagian besar responden memiliki perilaku yang cukup baik. Dari responden yang memiliki praktik menstrual hygiene cukup baik, sebagian besar memiliki tingkat pengetahuan yang kurang. 
Tabel 6. Tabulasi Silang Tingkat Pengetahuan dan Perilaku serta Hubungan Tingkat Pengetahuan Mengenai Kesehatan Reproduksi dengan Praktik Menstrual Hygiene

\begin{tabular}{|c|c|c|c|c|c|c|c|c|c|}
\hline & & \multicolumn{6}{|c|}{ Kategori Perilaku } & \multicolumn{2}{|r|}{ Total } \\
\hline & & \multicolumn{2}{|c|}{ Baik } & \multicolumn{2}{|r|}{ Cukup } & & Kurang & & \\
\hline & & & $\%$ & $\mathbf{n}$ & $\%$ & $\mathbf{n}$ & $\%$ & $\mathbf{n}$ & $\%$ \\
\hline Kategori & Baik & 0 & $0 \%$ & 2 & $66,7 \%$ & 1 & $33,3 \%$ & 3 & $100 \%$ \\
\hline Tingkat & Cukup & 3 & $27,3 \%$ & 6 & $54,5 \%$ & 2 & $18,2 \%$ & 11 & $100 \%$ \\
\hline Pengetahuan & Kurang & 2 & $12,5 \%$ & 10 & $62,5 \%$ & 4 & $25 \%$ & 16 & $100 \%$ \\
\hline
\end{tabular}

Penelitian sebelumnya yang dilakukan oleh Tarigan dan Hassan (2012), menyebutkan bahwa proporsi higiene menstruasi pada remaja yang menjadi respondennya lebih banyak dilakukan oleh remaja putri yang memiliki pengetahuan rendah daripada remaja yang memiliki pengetahuan tinggi. Sementara pada penelitian ini, remaja yang memiliki praktik menstrual hygiene yang baik dilakukan oleh remaja dengan tingkat pengetahuan cukup dan kurang. Beberapa penelitian serupa juga telah dilakukan namun memberikan hasil yang berbeda. Penelitian yang telah dilakukan oleh Tias (2014), mengenai faktor yang berhubungan dengan perilaku personal hygiene organ reproduksi wanita saat menstruasi pada anak sekolah dasar di kecamatan Kapongan kabupaten sebagian besar responden memiliki tingkat pengetahuan yang kurang mengenai kesehatan reproduksi terkait menstrual hygiene. Selain itu lebih dari sebagian besar responden sudah melakukan praktik menstrual hygiene yang cukup baik.

Fakta kurangnya pengetahuan siswa sekolah dasar mengenai menstrual hygiene diharapkan dapat membuat pendidik memberikan pengetahuan atau informasi tambahan mengenai kesehatan reproduksi kepada remaja untuk mempersiapkan diri menghadapi menarche. Penyampaian informasi mengenai kesehatan reproduksi sudah diberikan pada salah satu mata ajar tingkat sekolah dasar namun belum menyeluruh terkait dengan persiapan menarche dan menstrual hygiene yang ideal. Kerjasama dengan pihak puskesmas setempat yang melibatkan tim UKS juga dapat dilakukan untuk mensosialisasikan informasi kesehatan reproduksi remaja sebagai salah
Situbondo tidak sejalan dengan penelitian ini. Penelitian yang dilakukan oleh Tias tersebut menunjukkan hasil bahwa pengetahuan merupakan salah satu faktor pribadi yang memiliki hubungan dengan perilaku personal hygiene organ reproduksi anak sekolah dasar saat sedang menstruasi. Hasil dari Rahman (2014), juga mengemukakan bahwa pengetahuan mengenai menstruasi memberikan pengaruh terhadap perilaku personal hygiene pada saat menstruasi.

\section{SIMPULAN}

Penelitian ini dilaksanakan di SDN 4 Pacarkembang Surabaya dengan menggunakan total populasi sebagai respondennya. Berdasarkan hasil penelitian didapatkan hasil bahwa satu strategi agar menstrual hygiene pada usia menarche dapat menjadi lebih baik.

\section{DAFTAR PUSTAKA}

Alhamda, Syukra. 2015. Buku Ajar Sosiologi. Bukittinggi: Deepublish.

Allen, Kimberly. 2016. Theory, Research, and Practical Guidelines for Family Life Coaching. Switzerland: Springer Nature.

Andriyani, Avie. 2014. Edisi X, Tahun I Majalah Kesehatan Muslim: Tetap Prima Saat Haid Tiba. Yogyakarta: Pustaka Muslim.

Astuti, Lilis Puji, Nur Setiawati, dan Yuni Puji Widiastuti. 2016. Hubungan Tingkat Pengetahuan Remaja Putri Dengan Perilaku Personal Hygiene Organ Reproduksi Di Smp Negeri 3 Kendal. 
Dalam Jurnal Ilmu Kesehatan Vol. 6 No. 1, Januari 2016.

Azzam, U. 2012. La Tahzan untuk Wanita Haid. Jakarta : Qultum Media.

Badan Pusat Statistik. 2008. Survei Kesehatan Reproduksi Remaja Indonesia 2007. Jakarta.

Bahari, Hamid. 2012. Cara Mudah Atasi Keputihan. Yogyakarta: Buku Biru.

Clement, I. 2012. Manual of Community Health Nursing. India: Jaypee Brothers Medical Publishers.

Efendi, Ferry dan Makhfudli. 2009. Keperawatan Kesehatan Komunitas: Teori dan Praktik dalam Keperawatan. Jakarta: Salemba Medika.

Heryana, Ade. 2016. Perilaku Sehat dan Promosi Kesehatan. Artikel. Prodi Kesmas FIKES Universitas Esa Unggul Jakarta.

House S, T. Mahon, S Cavill, 2012. Part of Menstrual hygiene matters; A resource for improving menstrual hygiene around the world. Remake by UNICEF. Module One: Menstrual hygiene - the basics. http://www.wateraid.org/ /media/Files/Gl Rangka Menghadapi Menarche. Seminar Hasil Penelitian dan Pengabdian Masyrakat Dana BOPTN. https://publikasi.polije.ac.id/index.php/pro siding/article/viewFile/249/203. Diakses tanggal 30 April 2017 pukul 22.33 wib.

Nursalam. 2008. Konsep dan Penerapan Metodologi Penelitian Ilmu Keperawatan. Jakarta: Salemba Medika.

Oktavia, Nova. 2015. Sistematika Penulisan Karya Ilmiah. Yogyakarta: Deepublish Publisher.

Pitoyo, Ari dan Sri Purwaningtyas. 2010. Ilmu Pengetahuan Alam untuk SD/MI Kelas 6. Jakarta: Pusat Perbukuan Kementerian Pendidikan Nasional.

Prawirohardjo, Sarwono. 2011. Ilmu Kandungan. Jakarta: PT Bina Pustaka Sarwono Prawirohardjo.
obal/MHM-files/Toolkit1_LR.pdf?la=en. Diakses tanggal 30 Januari 2017 pukul 09.22 WIB.

Kholid, Ahmad. 2015. Promosi Kesehatan: Dengan Pendekatan Teori Perilaku, Media, dan Aplikasinya untuk Mahasiswa dan Praktisi Kesehatan. Depok: Rajawali Pers.

Mansur, Herawati dan Temu Budiarti. 2014. Psikologi Ibu dan Anak. Jakarta: Salemba Medika.

Mianoki, Andika, dkk. 2014. Majalah Kesehatan Muslim: Tetap Prima Saat Haid Tiba. Yogyakarta: Pustaka Muslim.

Noorkasiani, Heryati, dan Rita Ismail. 2009. Sosiologi Keperawatan. Jakarta: EGC.

Novianti, Yasnani, dan Erawan. 2016. Hubungan Pengetahuan, Sikap, Dan Tindakan Dengan Personal Hygiene Menstruasi Pada Remaja Putri Di SMP Negeri Satap Bukit Asri Kabupaten Buton Tahun 2016. Fakultas Kesehatan Masyarakat Universitas Halu Oleo. Artikel Jurnal.

Nurmawati, Ida dan Feby Erawantini. 2016. Pendidikan Kesehatan Reproduksi Pada Siswi SDN Tegal Gede 01 Dalam

Rahman, Nita. 2014. Faktor-Faktor yang Berhubungan dengan Perilaku Personal Hygiene pada Saat Menstruasi di SMP Muhammadiyah 5 Yogyakarta Tahun 2014. Naskah Publikasi. STIKES Aisyiyah Yogyakarta.

Sawyer, Susun M., et al. 2012. Asdolescene: a foundation for future health. The Lancet Volume 379, No. 9826, p1630-1640, 28 April 2012.

Sinclair, Contance. 2003. Buku Saku Kebidanan. Terjemahan oleh: Renata Komalasari, 2010. Jakarta: EGC.

Sulistyanto, Heri dan edy Wiyono. 2008. Ilmu Pengetahuan Alam untuk SD dan MI Kelas 6. Jakarta: Pusat Perbukuan Departemen Pendidikan Nasional. 
Sulistyowati dan Sukarno. 2006. Ilmu Pengetahuan Alam untuk Kelas 6. Jakarta: Pusat Perbukuan Departemen Pendidikan Nasional.

Suparno, Paul. 2001. Teori Perkembangan Kognitif Jean Piaget. Yogyakarta: Kanisius.

Tarigan, Windurenny Jacinta dan Anwar Hassan. 2012. Gambaran Tentang Hubungan Pengetahuan dan Sikap dengan Praktik Hygiene Menstruasi pada Remaja Putri Kelas 7 dan 8 di SMPN 141 Jakarta Selatan tahun 2012. Artikel Jurnal. FKM UI 2013.

Tias, Sumiyati Andayaning. 2014. Faktor yang Berhubungan dengan Perilaku Personal Hygiene Organ Reproduksi Wanita pada Anak Sekolah Dasar di Kecamatan Kapongan Kabupaten Situbondo. Skripsi. Fakultas Kesehatan Masyarakat Universitas Jember.

UNICEF. 2011. Asdolescene An Age of Opportunity. New York.

United Nations. 2014. Programme of Action Twentieth Anniversary Edition, Adopted at the International Conference on Population and Development Cairo, 5 13 September 1994. UNFPA.

WaterAid. 2013. Menstrual Hygiene Matters. http://www.wash-united.org/ourwork/issues/menstrual-hygiene-

management/articles/our-work-issuesmenstrual-hygiene-management. Diakses pada 30 Januari 2017 pukul 09.12 WIB.

Wijaya, Agung, Budi Suryatin dan Das Salirawati. 2008. IPA Terpadu Kelas VIIIA. Jakarta: Grasindo. 